Gut, 1976, 17, 133-138

\title{
Effect of cimetidine on 24-hour intragastric acidity in normal subjects
}

\author{
R. E. POUNDER, J. G. WILliams, G. J. MILTON-THOMPSON, AND \\ J. J. MISIEWICZ
}

From the Medical Research Council Gastroenterology Unit, Central Middlesex Hospital, London, and Royal Naval Hospital, Plymouth, Devon

SUMMARY The effect of $\mathrm{H}_{2}$-receptor blockade on intragastric acidity was studied in nine normal males. The $\mathrm{pH}$ of their gastric contents was measured at hourly daytime and two hourly nighttime intervals for 48 hours. The subjects ate identical meals, drank identical volumes of fluid, and smoked the same number of cigarettes during the two study days. Their physical activity was unrestricted in a ward environment. Blood cimetidine and plasma gastrin were measured in serial blood samples. The nine subjects were treated in random sequence with cimetidine $0.8-1.0 \mathrm{~g}$ on one day and placebo capsules on the other. The drug was given in four divided doses: four subjects received it before, and five after, the three main meals. All took the fourth dose at bedtime. Replicate studies in an additional subject given placebo on both study days showed good reproducibility $(r=0.80, \mathrm{P}<0.01)$. Cimetidine therapy decreased intragastric acidity in all nine subjects. The decrease was similar in the two groups taking the drug before or after meals, mean $24 \mathrm{~h}$ intragastric hydrogen ion activity being lowered by 70 and $72 \%$ respectively. Nocturnal anacidity was recorded in only two of 45 samples. Administration of cimetidine before meals produced earlier and higher drug blood levels than post-prandial medication, but when it was taken after food the blood levels were highest at the time when the buffer capacity of the food was waning. Blood concentrations of cimetidine exceeded the secretory $\mathrm{IC}_{50}$ level for most of the time between doses. The results show that cimetidine $0 \cdot 8-1.0 \mathrm{~g} /$ day in four divided doses produces a striking and consistent decrease of intragastric acidity. Although variation in the timing of the dose in relation to meals did not affect the decrease of acidity, the absorption data suggest that patients should take the drug after meals.

Cimetidine is a new histamine $\mathrm{H}_{2}$-receptor antagonist, which in man has a potency similar to metiamide for the inhibition of acid secretion stimulated by pentagastrin or food (Black et al., 1972; Black et al., 1973; Mainardi et al., 1974; Brimblecombe et al., 1975; Burland et al., 1975; Pounder et al., 1975a; Henn et al., 1975; Richardson and Fordtran, 1975; Richardson et al., 1975).

The thiourea residue in metiamide, which is thought to have been responsible for the reversible marrow depression that occurred in seven patients receiving the drug, has been replaced by a cyanoguanidine moiety in cimetidine.

In order to determine the optimal time of medication before starting clinical trials of the new com-

Address for correspondence: R. E. Pounder, M.R.C. Gastroenterology Unit, Central Middlesex Hospital, London, NW10 7NS.

Received for publication 10 November 1975 pound, we have studied the effect of oral cimetidine on the intragastric acidity of fully ambulant normal subjects eating a normal diet, under conditions similar to ordinary daily activity.

\section{Methods}

Ten normal male volunteers were admitted for $48 \mathrm{~h}$ to an especially allocated hospital ward at 7 a.m. after an overnight fast. A 10 FR nasogastric tube was positioned under $x$-ray control so that the tip was in the most dependent part of the stomach. The subjects ate identical meals, consumed the same volume of identical fluids, and smoked the same number of cigarettes at the same times on both days of the study (Table 1). The menu was settled by prior discussion with the subjects, to ensure that it was palatable to all. No food or fluid was taken between the meals. Detailed individual logs of ad lib cigarette 


\begin{tabular}{|c|c|c|c|c|c|}
\hline Time & Meal & $\begin{array}{l}\text { Protein } \\
\text { (g) }\end{array}$ & $\begin{array}{l}\text { Fat } \\
(\mathrm{g})\end{array}$ & $\begin{array}{l}\mathrm{CHO} \\
(\mathrm{g})\end{array}$ & $\begin{array}{l}\text { Energy } \\
\text { value } \\
(k J)\end{array}$ \\
\hline 08.30 & $\begin{array}{l}\text { Breakfast } \\
\text { Cereal } \\
\text { Gammon and tomato } \\
\text { Toast and marmalade } \\
\text { Tea }\end{array}$ & & & & \\
\hline 11.00 & Coffee & $\begin{array}{r}46 \\
2\end{array}$ & $\begin{array}{r}42 \\
2\end{array}$ & $\begin{array}{r}105 \\
3\end{array}$ & $\begin{array}{r}4068 \\
166\end{array}$ \\
\hline 13.00 & $\begin{array}{l}\text { Lunch } \\
\text { Roast chicken and } \\
\text { sausage } \\
\text { Vegetables } \\
\text { Apple and custard } \\
\text { Tea* }\end{array}$ & 51 & 32 & 76 & 3301 \\
\hline $\begin{array}{l}16.00 \\
18.30\end{array}$ & $\begin{array}{l}\text { Tea } \\
\text { Dinner } \\
\text { Grilled steak } \\
\text { Vegetables } \\
\text { Jelly and cream } \\
\text { Tea* }\end{array}$ & 1 & 1 & 1 & 83 \\
\hline \multirow[t]{2}{*}{22.00} & $\begin{array}{l}\text { Tea* } \\
\text { Nightcap } \\
\text { Cheese and biscuits } \\
\text { Meat extract drink }\end{array}$ & 11 & 32 & 10 & 1577 \\
\hline & & 144 & 143 & 248 & 11911 \\
\hline
\end{tabular}

Table 1 Daily food intake

*Plus 284-568 ml beer, dependent on individual preference, but the same amount each day.

and fluid consumption were kept by the subjects during the first study day and the same intake was repeated on the second day by reference to the records. The subjects were fully ambulant, ate their meals at a table, were entertained by reading, television, and films, and played games ranging from dominoes to table tennis.

None of the volunteers had a history of dyspepsia. A pentagastrin test $(0.6 \mathrm{mg}$ subcutaneously) before the study had demonstrated that all the subjects secreted acid (Table 2).

Five millilitre samples of gastric contents were aspirated from every subject every hour from 8 a.m. to midnight and every two hours from 2 a.m. to 8 a.m. Immediately after collection, the $\mathrm{pH}$ of gastric aspirates was measured to the nearest $0 \cdot 1 \mathrm{pH}$ unit using a combined glass electrode and $\mathrm{pH}$ meter (Radiometer, Copenhagen). Aspirates collected within $2 \mathrm{~h}$ of medication were replaced in the stomach in order to ensure complete absorption of the drug. The $\mathrm{pH}$ electrode was calibrated with standard buffers of $\mathrm{pH} 2 \cdot 0,4 \cdot 0$, and $7 \cdot 0$. The calibration was checked immediately before each batch of measurements. The result of each $\mathrm{pH}$ measurement of hydrogen ion activity was converted to $\mathrm{mmol} / \mathrm{l}$ for analysis.

Medication consisted of cimetidine or identically appearing placebo capsules; one subject received the placebo on both days of the study. Five subjects received cimetidine on the first day and four on the second day, the order of treatment being allocated

\begin{tabular}{llll}
\hline & $\begin{array}{l}\text { Drug after } \\
\text { meals } \\
(n=5)\end{array}$ & $\begin{array}{l}\text { Drug before } \\
\text { meals } \\
(n=4)\end{array}$ & $\begin{array}{l}\text { Placebo } \\
\text { both days } \\
(n=1)\end{array}$ \\
\hline Age (yr) & $\begin{array}{l}34 \cdot 2 \pm 5 \cdot 0 \\
(19-45)\end{array}$ & $\begin{array}{l}33 \cdot 5 \pm 2 \cdot 9 \\
(25-37)\end{array}$ & 27 \\
Weight (kg) & $\begin{array}{l}82 \cdot 9 \pm 3 \cdot 7 \\
(75 \cdot 8-95 \cdot 5)\end{array}$ & $\begin{array}{l}76 \cdot 2 \pm 8 \cdot 1 \\
(53 \cdot 8-90 \cdot 9)\end{array}$ & $76 \cdot 5$ \\
Acid output & $\begin{array}{l}3 \cdot 1 \pm 1 \cdot 4 \\
(1 \cdot 2-9 \cdot 2)\end{array}$ & $\begin{array}{l}3 \cdot 0 \pm 0 \cdot 8 \\
(1 \cdot 2-5 \cdot 2)\end{array}$ & $2 \cdot 4$ \\
Mmol/h) basal & $\begin{array}{l}29 \cdot 4 \pm 3 \cdot 5 \\
(22 \cdot 2-42 \cdot 3)\end{array}$ & $\begin{array}{l}38 \cdot 5 \pm 8 \cdot 4 \\
(21 \cdot 3-54 \cdot 0)\end{array}$ & $15 \cdot 6$ \\
MAOPg & 3 & 3 & 0 \\
\hline
\end{tabular}

Table 2 Details of the normal volunteers (mean \pm SEM (range) )

randomly. Independently of that randomization, the subjects were divided into two comparable groups based on the results of their pentagastrin test and cigarette consumption (Table 2); four subjects received the capsules $30 \mathrm{~min}$ before and five subjects $30 \mathrm{~min}$ after, the three main meals of the day. All received the last dose $30 \mathrm{~min}$ after the night-time snack. The dose of cimetidine was $200 \mathrm{mg}$ four times a day, except that in four subjects one $200 \mathrm{mg}$ dose was replaced by $400 \mathrm{mg}$ : in two subjects before, and in two after, dinner. As the gastric acidity levels after the $400 \mathrm{mg}$ dose were similar to those after $200 \mathrm{mg}$, the results were pooled for analysis. Because the numbers in each group of this study are small, the results have not been subjected to statistical analysis.

Fasting venous plasma gastrin concentrations were determined by radioimmunoassay (Russell et al., submitted for publication). Whole blood cimetidine concentrations were measured by highpressure liquid chromatography (Smith, Kline and French Laboratories, Philadelphia). Detailed studies of cimetidine absorption in relation to breakfast or dinner were performed once during the study in each of the nine subjects receiving the drug: indwelling cannulae were used for repeated venous sampling. Haematological and biochemical safety tests were performed before and after the study.

The subjects were unaware of the nature of medication taken on a particular day. They all gave their informed consent to the study, which was approved by the appropriate ethical committees.

\section{Results}

The study was well tolerated by all the subjects, who reported no unwanted effects associated with the drug. No abnormalities were detected in the safety profiles. The various sampling procedures did not interfere with appetite, eating, or recreational arrangements. Beer and cigarette consumption 


\begin{tabular}{llll}
\hline & $\begin{array}{l}\text { Drug after } \\
\text { meals } \\
(n=5)\end{array}$ & $\begin{array}{l}\text { Drug before } \\
\text { meals } \\
(n=4)\end{array}$ & $\begin{array}{l}\text { Placebo } \\
\text { both days } \\
(n=1)\end{array}$ \\
\hline $\begin{array}{l}\text { Beer intake } \\
\text { (ml/24 h) }\end{array}$ & $\begin{array}{l}965 \pm 114 \\
(568-1136)\end{array}$ & $\begin{array}{l}909 \pm 57 \\
(852-1136)\end{array}$ & 852 \\
$\begin{array}{l}\text { Urine output } \\
\text { (ml/24 h) }\end{array}$ & $\begin{array}{l}1482 \pm 231 \\
(955-2325)\end{array}$ & $\begin{array}{l}1787 \pm 204 \\
(1200-2130)\end{array}$ & 1600 \\
$\begin{array}{l}\text { Cigarettes } \\
(24 \mathrm{~h})\end{array}$ & $\begin{array}{l}7 \cdot 4 \pm 3 \cdot 1 \\
(0-14)\end{array}$ & $\begin{array}{l}13 \cdot 0 \pm 5 \cdot 5 \\
(0-27)\end{array}$ & 0 \\
\hline
\end{tabular}

Table 3 Beer intake, urine output and cigarette consumption (mean $\pm S E M$ (range) )

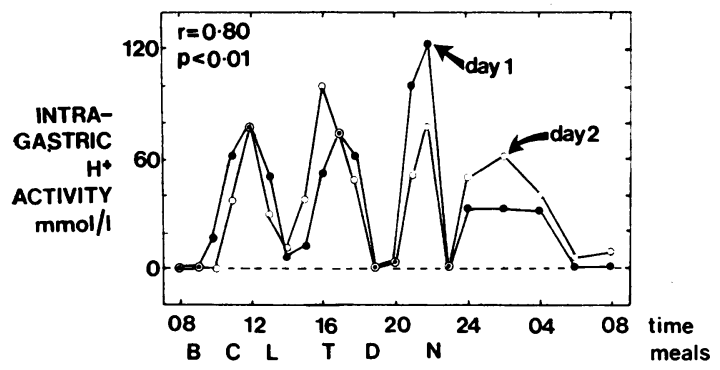

Fig. 1 The intragastric acidity of one subject receiving placebo on two successive days.

and urine output were similar in both groups of subjects (Table 3). Good reproducibility between two days of the study was demonstrated by the acidity of gastric aspirates from the subject who received the placebo on both days $(r=0.80$, $P<0.01$; Fig. 1). In that subject, the mean hydrogen ion activity was $35.2 \mathrm{mmol} / 1$ and $38.7 \mathrm{mmol} / \mathrm{l}$ during the two successive $24 \mathrm{~h}$ periods, an overall change of $+9 \%$.

Regardless of medication, intragastric acidity was decreased in all the subjects after each main meal, but cimetidine therapy was associated with a prolonged decrease which persisted until the next meal (Fig. 2). The decrease of mean hydrogen ion activity during each $24 \mathrm{~h}$ period was similar in both treatment groups, diminishing from the placebo day level of $29 \cdot 1 \mathrm{mmol} / 1$ to $8 \cdot 7 \mathrm{mmol} / 1(-70 \%)$ when cimetidine was taken before food, and from $34 \cdot 1$ to $9.4 \mathrm{mmol} / 1(-72 \%)$ when it was taken after food. The hourly pattern of decreased activity was similar in the pre- and post-prandially treated groups.

Absorption of cimetidine was faster and resulted in high peak blood levels in most of the subjects who received it before meals (Fig. 3). With the preprandial $200 \mathrm{mg}$ dose, peak blood concentrations of 4.12 and $6.40 \mu \mathrm{mol} / 1$ were attained within $1 \mathrm{~h}$ of administration. However, when cimetidine $200 \mathrm{mg}$ was taken after the meal, absorption was delayed for $30 \mathrm{~min}$ and the peak blood concentrations of $2 \cdot 72$,

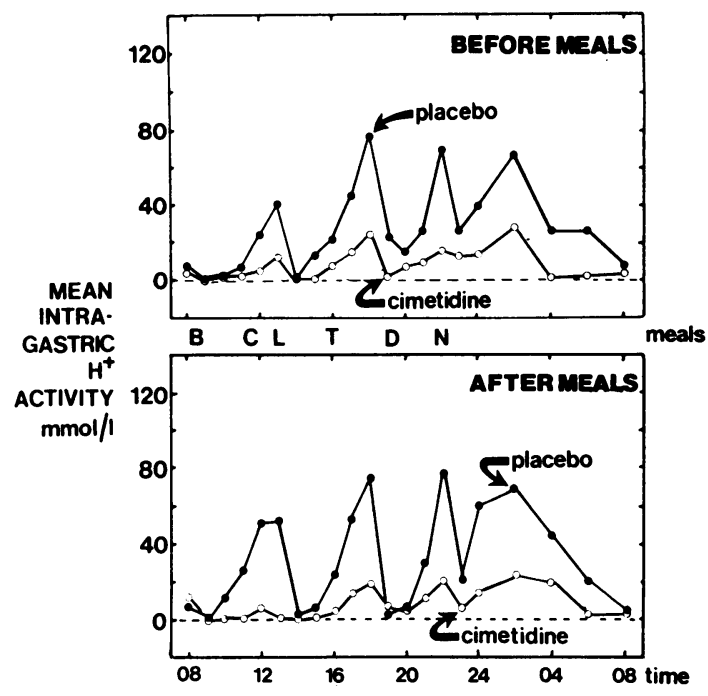

Fig. 2 Mean intragastric acidity: capsules before food in four subjects, and after food in five subjects.

$B=$ breakfast, $C=$ coffee, $L=$ lunch, $T=$ tea, $D=$ dinner,$N=$ nightcap.

$4 \cdot 32$, and $4.52 \mu \mathrm{mol} / 1$ were not reached until $1 \frac{1}{2}$ to $2 \frac{1}{2} \mathrm{~h}$ after medication. Similar absorption curves were obtained with the post-prandial $400 \mathrm{mg}$ dose, although peak blood levels were somewhat higher (4.84 and $6.00 \mu \mathrm{mol} / \mathrm{l})$. The very high peak level of $11.60 \mu \mathrm{mol} / 1$ attained by one subject $1 \mathrm{~h}$ after preprandial $400 \mathrm{mg}$ cimetidine was probably related to his low body weight $(54 \mathrm{~kg}$, dose $7 \cdot 41 \mathrm{mg} / \mathrm{kg})$. The other individual who received a $400 \mathrm{mg}$ preprandial dose of the drug had a lower peak blood level $(6.84 \mu \mathrm{mol} / \mathrm{l}$, weight $84 \mathrm{~kg}$, dose $4.76 \mathrm{mg} / \mathrm{kg})$. Doubling the dose of cimetidine to $400 \mathrm{mg}$ at dinnertime in four subjects did not result in a greater

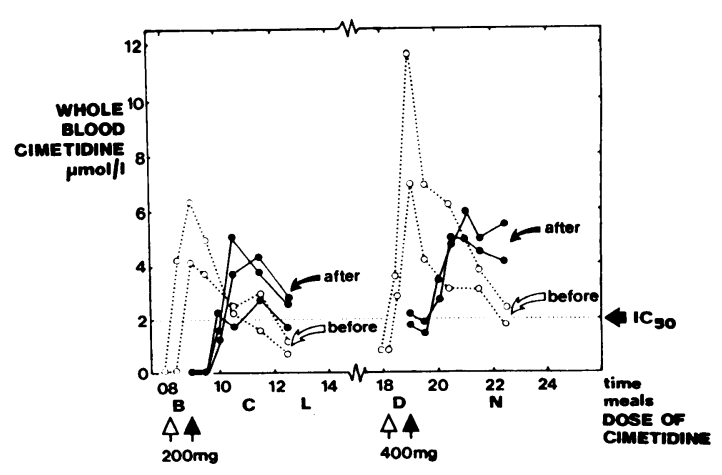

Fig. 3 Whole blood cimetidine concentrations following $200 \mathrm{mg}$ at breakfast (five subjects) and $400 \mathrm{mg}$ at dinner (four subjects). 


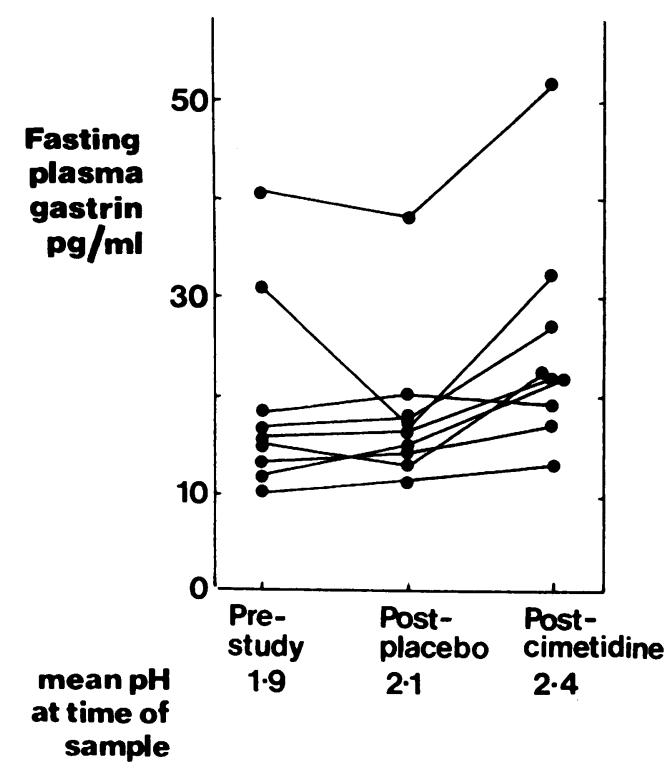

Fig. 4 Fasting plasma gastrin levels in normal volunteers on each morning of the study and mean intragastric pH at time of blood sampling.

decrease of acidity than that recorded in the five remaining subjects who received $200 \mathrm{mg}$.

Mean fasting plasma gastrin levels in the nine subjects receiving cimetidine were similar in the mornings before the study and after the placebo day $(19 \cdot 54 \mathrm{pg} / \mathrm{ml} \pm$ SEM $3 \cdot 40$, range $10-41$, and $18.44 \mathrm{pg} / \mathrm{ml} \pm 2 \cdot 43$, range $13-37$, respectively). Mean fasting plasma gastrin was higher on the morning after the cimetidine than on either of the two control days $(25.55 \mathrm{pg} / \mathrm{ml} \pm 4.06$, range 14-54). This increase was due to a rise of plasma gastrin in five of the nine subjects (Fig. 4) but was not related to the timing or the size of the evening dose of cimetidine.

\section{Discussion}

Serial measurements of intragastric $\mathrm{pH}$ are suitable for recording the effects of diet or drugs on gastric acidity (Nichol, 1939; James and Pickering, 1949; Rowlands et al., 1952; Atkinson, 1954; Kasich and Agyros, 1958; Bingle and Lennard-Jones, 1960; Vakil et al., 1963; Lennard-Jones and Babouris, 1965; Babouris et al., 1965). The major advantage of this technique is that data can be collected during a reasonably long period in subjects whose diet and activity are similar to normal life. Experiments of the type described in this paper, with each subject acting as his own control, allow the effect of an antisecretory compound on gastric acidity to be measured during a prolonged period, while taking into account all the variables that affect the stomach in daily life.

Moore and Scarlata (1965) published a series of activity coefficients for the conversion of hydrogen ion activity, as measured by a glass electrode, to hydrogen ion concentration or total titratable acidity. This conversion has not been applied to our results, because the coefficients do not apply to gastric juice containing food buffer. Moreover, it is possible that hydrogen ion activity may be more important than total titratable acidity in the pathogenesis of duodenal ulceration. Moore (1968) also reported that the use of commercial buffers may result in errors of $\mathrm{pH}$ determination when glass

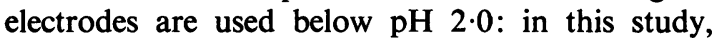
we measured $\mathrm{pH}$ to the nearest $0 \cdot 1$ unit and the described errors were well within that limit of accuracy.

Replicate measurements in the one subject who received placebo on both days of the study correlate significantly, and confirm the reliability of the technique. Intragastric acidity decreased after each main meal in all the subjects, supporting the observation of Lennard-Jones and Babouris (1965) that food buffers the acid secreted after a meal for approximately two hours.

Cimetidine decreased the overall intragastric hydrogen ion activity by $71 \%$, with every subject responding to the drug. Pentagastrin-stimulated acid output in the nine subjects was in the upper parts of the normal range, indicating that the drug inhibited the secretory response to food of a parietal cell mass compatible with the occurrence of duodenal ulceration. Although the number of subjects so far studied is small, published data suggest that the degree of inhibition of gastric secretion by cimetidine in normal subjects and duodenal ulcer patients is similar (Pounder et al., 1975a, b; Henn et al., 1975).

In terms of mean intragastric hydrogen ion activity, there was no major difference between the two groups who took the drug either before or after food. This was despite the earlier and high blood concentrations of cimetidine in those who took it before meals, and the delayed peak concentrations in those who took it post-prandially. On the basis of previous studies, we suggested that cimetidine should be given with or after a meal (Pounder et al., 1975a). This was because slower absorption from the gut resulted in prolonged bioavailability of the compound, particularly at the time when the buffering capacity of the meal was waning due to gastric emptying.

The results of the present study confirm that the timing of a dose of cimetidine in relation to food does affect its absorption, but this does not appear 
to affect intragastric acidity under these conditions. Regular administration of $200 \mathrm{mg}$ four times daily should ensure drug levels above or near the $\mathrm{IC}_{50}$ level of $2 \mu \mathrm{mol} / \mathrm{l}$ (Burland et al., 1975), and a decreased acidity throughout the $24 \mathrm{~h}$. In a clinical situation, when a dose of cimetidine may be delayed or omitted, medication taken after food should provide effective blood levels for a longer period, and cover the break in therapy.

In patients with duodenal ulcer a single oral dose of $400 \mathrm{mg}$ metiamide profoundly inhibited nocturnal acid secretion, anacidity being recorded for several hours in eight of 11 subjects (Milton-Thompson et al., 1974). In the present study, anacidity was recorded in only two of 45 nocturnal samples. As metiamide and cimetidine have comparable inhibitory activities for histamine or pentagastrin stimulated gastric acid secretion in man (Brimblecombe et al., 1975), these dissimilar results could be due either to differences of technique, or more likely to the different environmental conditions of the two studies. Nocturnal acid secretion in the duodenal ulcer patients was unstimulated and measured after a five hour fast in hospitalized patients (MiltonThompson et al., 1974). By contrast, in the present study, acid secretion was almost continuously stimulated by a high protein diet and a meat extract evening drink. Physical and mental activity, smoking, and alcohol may have also played a part. The combined results of our studies suggest that, for the best control of nocturnal acid secretion, patients with duodenal ulcer might be advised to take only a light meal some time before the bedtime dose of cimetidine.

The small rise in fasting plasma gastrin after $24 \mathrm{~h}$ treatment with cimetidine was probably secondary to the decreased acidity during the night and early morning. This idea is in line with our previous report that cimetidine had no effect on the secretion of gastrin in response to a meal when intragastric $\mathrm{pH}$ was held at 5.50 (Pounder et al., 1975a). It also agrees with the finding that, when the intragastric $\mathrm{pH}$ is not controlled, a rise in plasma gastrin follows the administration of metiamide (Barbezat et al., 1975). These observations raise the possibility that prolonged treatment with $\mathrm{H}_{2}$-receptor antagonists may be followed by a sustained rise of plasma gastrin. The implications of this with regard to the long-term treatment of gastric or duodenal ulcer will have to be reviewed as experience with the drug accumulates.

We are grateful to the Clinical Research Group, Smith, Kline and French Laboratories, Welwyn Garden City, for supplies of cimetidine and for arranging the estimation of blood cimetidine levels. We thank Mr R. C. G. Russell, Surgical Unit,
St. Mary's Hospital, London, W2, for the radioimmunoassay of plasma gastrin. We also thank the medical officer-in-charge, the dietitian, Mrs Sutton, and the staff of the Departments of Pathology and Radiology, the Royal Naval Hospital, Stonehouse, Plymouth, for their help in arranging the study.

\section{References}

Atkinson, M. (1954). The use of Banthine in the control of gastric acidity. Gastroenterology, 26, 288-298.

Babouris, N., Fletcher, Janet, and Lennard-Jones, J. E. (1965). Effect of different foods on the acidity of the gastric contents in patients with duodenal ulcer. Part 2: effect of varying the size and frequency of meals. Gut, 6, 118-120.

Barbezat, G. O., Grant, B., Bank, S., and Vinik, A. (1975). The effect of histamine $\mathbf{H}_{2}$-receptor blockade with metiamide on serum gastrin levels in man. Gut, 16, 186-187.

Bingle, J. P., and Lennard-Jones, J. E. (1960). Some factors in the assessment of gastric anti-secretory drugs by a sampling technique. Gut, 1, 337-344.

Black, J. W., Duncan, W. A. M., Durant, C. J., Ganellin, C. R., and Parsons, E. M. (1972). Definition and antagonism of histamine $\mathrm{H}_{2}$-receptors. Nature, 236, 385-390.

Black, J. W., Duncan, W. A. M., Emmett, J. C., Ganellin, C. R., Hesselbo, T., Parsons, M. E., and Wyllie, J. H. (1973). Metiamide-an orally active histamine $\mathrm{H}_{2}$-receptor antagonist. Agents and Actions, 3, 133-137.

Brimblecombe, R. W., Duncan, W. A. M., Durant, G. J., Emmett, J. C., Ganellin, C. R., and Parsons, M. E. (1975). Cimetidine-a non-thiourea $\mathrm{H}_{2}$-receptor antagonist. Journal of International Medical Research, 3, 86-92.

Burland, W. L., Duncan, W. A. M., Hesselbo, T., Mills, J. G., Sharpe, P. C., Haggie, S. J., and Wyllie, J. H. (1975). Pharmacological evaluation of cimetidine, a new histamine $\mathrm{H}_{2}$-receptor antagonist, in healthy man. British Journal of Clinical Pharmacology. 2, 481-486.

Henn, R. M., Isenberg, J. I., Maxwell, V., and Sturdevant, R. A. L. (1975). Inhibition of gastric acid secretion by cimetidine in patients with duodenal ulceration. New England Journal of Medicine, 293, 371-375.

James, A. H., and Pickering, G. W. (1949). The role of gastric acidity in the pathogenesis of peptic ulcer. Clinical Science, 8, 181-210.

Kasich, A. M., and Agyros, T. G. (1958). The effect of a prolonged acting form of propantheline bromide (Probanthine) on hydrogen ion concentration of gastric juice as observed in forty-eight-hour gastric analysis. Gastroenterology, 34, 232-238.

Lennard-Jones, J. E., and Babouris, N. (1965). Effect of different foods on the acidity of the gastric contents in patients with duodenal ulcer. Part 1: a comparison between two 'therapeutic' diets and freely-chosen meals. Gut, 6, 113-117.

Mainardi, M., Maxwell, V., Sturdevant, R. A. L., and Isenberg, J. I. (1974). Metiamide, an $\mathrm{H}_{2}$-receptor blocker, as inhibitor of basal and meal-stimulated gastric acid secretion in patients with duodenal ulcer. New England Journal of Medicine, 291, 373-376.

Milton-Thompson, G. J., Williams, J. G., Jenkins, D. J. A., and Misiewicz, J. J. (1974). Inhibition of nocturnal acid secretion in duodenal ulcer by one oral dose of metiamide. Lancet, 1, 693-694.

Moore, E. W. (1968). Determination of $\mathrm{pH}$ by the glass electrode: $\mathrm{pH}$ meter calibration for gastric analysis. Gastroenterology, 54, 501-507.

Moore, E. W., and Scarlata, R. W. (1965). The determination of gastric acidity by the glass electrode. Gastroenterology, 49, 178-188. 
Nichol, B. M. (1939). Control of gastric acidity in peptic ulcer. Lancet, 2, 881-884.

Pounder, R. E., Williams, J. G., Misiewicz, J. J., and MiltonThompson, G. J. (1975b). The 24-hour control of intragastric $\mathrm{pH}$ by cimetidine, a new $\mathrm{H}_{2}$-receptor antagonist, in normal subjects and patients with duodenal ulcer. (Abstract). Gut, 16, 831.

Pounder, R. E., Williams, J. G., Russell, R. C. G., Misiewicz, J. J., and Milton-Thompson, G. J. (1975a). New histamine $\mathrm{H}_{2}$-receptor antagonist inhibits food-stimulated gastric acid secretion. (Abstract). Gut, 16, 397.

Richardson, C. T., Bailey, B. A., Walsh, J. H., and Fordtran, J. S. (1975). The effect of an $\mathrm{H}_{2}$-receptor antagonist on food-stimulated acid secretion, serum gastrin, and gastric emptying in patients with duodenal ulcers. Journal of
Clinical Investigation, 55, 536-542.

Richardson, C. T., and Fordtran, J. S. (1975). Effect of cimetidine, a new histamine $\mathbf{H}_{2}$ receptor antagonist, on foodstimulated acid secretion in duodenal ulcer patients. (Abstract). Gastroenterology, 68, 972.

Rowlands, E. N., Wolff, H. H., and Atkinson, M. (1952) Clinical assessment of drugs which inhibit gastric secretion with special reference to hexamethonium. Lancet, 2 , 1154-1158.

Russell, R. C. G., Bloom, S. R., Fielding, L. P. and Bryant, M. G. Current problems in the measurement of gastrin. Submitted for publication.

Vakil, B. J., Mulekar, A. M., and Misra, N. C. (1963). 24-hour gastric analysis. Journal of the Indian Medical Association. 41, 342-346.

\section{The January 1976 Issue}

\section{THE JANUARY 1976 ISSUE CONTAINS THE FOLLOWING PAPERS}

Detection of $\mathrm{HB}_{\mathrm{s}} \mathrm{Ag}$ in fixed liver tissue-use of a modified immunofluorescent technique and comparison with histochemical methods B. PORTMANN, R. M. GALbRAith, A. L. W. F. EDDleston, A. J. ZUCKERMAN, AND ROGER WILLIAMS

Hepatitis $\mathrm{B}$ antigen $\left(\mathrm{HB}_{\mathrm{s}} \mathrm{Ag}\right)$ and/or antibodies (anti-HB $\mathbf{B}_{\mathbf{s}}$ and anti-HB $\mathrm{B}_{\mathrm{c}}$ ) in fulminant hepatitis: pathogenic and prognostic significance C. G. TREPO, D. ROBERT, J. MOTIN, D. TREPO, M. SEPETJIAN, AND A. M. PRINCE

Assessment of endoscopic retrograde choliangiopancreatography (ERCP) and pure pancreatic juice cytology in patients with pancreatic disease A. R. W. HATFIELD, A. SMITHIES, R. WILKINS, AND A. J. LEVI

Prostaglandin release in canine acute haemorrhagic pancreatitis GEOFFREY GLAZER AND ALAN BENNETT

Oral administration of a chymotrypsin-labile peptide-a new test of exocrine pancreatic function in man (PFT) K. GYR, G. A. STALDER, I. SCHIFFMANN, C. FEHR, D. VONDERSCHMITT, AND H. FAHRLAENDER

Effect of prostaglandin $15(R) 15$ methyl-E $E_{2}$ methyl ester on aspirin and taurocholic acid-induced gastric mucosal haemorrhage in rats H. A. CARMICHAEL, L. NELSON, R. I. RUSSELL, V. CHANDRA, A. LYON, AND K. M. COCHRAN
Upper gastrointestinal bleeding in cirrhosis: clinical and endoscopic correlations J. TERÉS, J. M. BORDAS, C. BRU, F. DIAZ, M. BRUGUERA, AND J. RODES

Review of five cases of early gastric carcinoma D. I. FEVRE, P. H. R. GREEN, P. J. BARRATT, AND G. S. NAGY

Effect of vagotomy on the gastric secretory response to intraduodenal osmotic agents in man A. $S$. WARD

Effects of aspirin on gastric prostaglandin E (PGE) and acid output in normal subjects C. CHILD, W. JUBIZ, AND J. G. MOORE

Abnormal intestinal bile acid distribution in azotaemic man: a possible role in the pathogenesis of uraemic diarrhoea S. J. GORDON, L. J. MILLER, L. J. HAEFFNER, M. D. KINSEY, AND O. D. KOWLESSAR

Limitations of ultracentrifugation and in vivo dialysis as methods of stool analysis C. W. I. OWENS AND W. PADOVAN

Role of the granuloma in recurrent Crohn's disease R. E. GLASS AND W. N. W. BAKER

Notes and activities

Notes on books

Copies are still available and may be obtained from the PUBLISHING MANAGER, BRITISH MEDICAL ASSOCIATION, TAVISTOCK SQUARE, LONDON, WC1H 9JR, price $£ 2.00$ including postage 